\title{
Value Creation for the After-Sales Services: Organizational and Strategic Perspectives*
}

\author{
Nouha Taifi \\ University Mohammed V, Rabat, Morocco \\ Angelo Corallo, Marco De Maggio, Giuseppina Passiante \\ University of Salento, Lecce, Italy
}

\begin{abstract}
As a part of the product development process, the after-sales services are not only a source of innovation, but also they benefit from value creation through new managerial methodologies for the achievement of competitive advantage and customer satisfaction. The objective of the paper is to further understand value creation for the after-sales services. We present the case of the creation of a new business for the after-sales services for the entrance into a new market. The new business is created by two gurus in the aerospace industry. A typology of guidelines is derived, based on organizational and strategic perspectives, for the after-sales services value creation and the guidelines for the creation of a new business as well as for the entrance of into a new market are presented.
\end{abstract}

Keywords: after-sales services, value creation, new market entrance

\section{Introduction}

The servitization process is the starting point toward the recognition of the growing value of services as compared to manufactured products; in complex industries, this contributes to the move from the industrial to the post-industrial economy. Indeed, the growth derived from physical products sales has become increasingly limited, thus the move to post-industrial economy has urged a refocus of the corporate strategy of the firms. The fast technology maturity and product lifecycle, the increasing cost pressure, the decreasing of margins, the radical change of market dynamics require the identification of new value creation concepts and sources able to ensure the growth of the firms (Mattmüller \& Irion, 2004).

The after-sales services represent an important source of revenues and economic performance (Saccani, Johansson, \& Perona, 2007) and the manufacturing and design firms are aware of the important role of the

\footnotetext{
* Fondo per Gli Investimenti della Ricerca di Base (FIRB): Toward Evolving Knowledge-Based interNetworked Enterprise (TEKNE), Italian Research Program, Ministry of Instruction, Higher Education and Research (MIUR).

Nouha Taifi, Ph.D., Assistant Professor, Department of Industrial Engineering, Mohammadia School of Engineering, University Mohammed V.

Angelo Corallo, Assistant Professor, Department of Innovation Engineering and Center for Business Innovation, Euro-Mediterranean Incubator in E-Business management, University of Salento.

Marco De Maggio, Ph.D., Researcher, Center for Business Innovation, Euro-Mediterranean Incubator in E-Business Management, University of Salento.

Giuseppina Passiante, Full Professor, Department of Innovation Engineering and Center for Business Innovation, Euro-Mediterranean Incubator in E-Business management, University of Salento.

Correspondence concerning this article should be addressed to Nouha Taifi, Avenue Ibn Sina, 10090, Rabat, Morocco. E-mail: taifi@emi.ac.ma.
} 
after-sales services in the product and new product development processes and business performance (Wheelwright \& Clark, 1992). The manufacturing firms take care of after-sales services in several ways; they can have either direct contact with the customers and provide the after-sales services, or delegate to a third party the after-sales services. In the automotive industry, for cost optimization and risk-sharing, the manufacturing firms tend to outsource the after-sales services (Taifi, 2008). Thus, whether internal or external to the firms, the focus on the after-sales services, from an organizational and strategic point of view, is increasing.

Therefore, we question what the value creation for the after-sales services is, which elements lead to this value creation and what the types of these elements are. In the next sections, we present the theoretical background related to the areas of service sciences and strategic management with a particular focus on the after-sales services and the business processes and networks that bring them to their fruition. Then, following are the research methodology and data collection, and the results part.

\section{Theoretical Background}

\section{Service Sciences, Engineering, and Innovation}

Service science, management, and engineering (SSME) are three interconnected fields involved in many types of industries as the software, automotive and aerospace industries. Li, Wang, Yu, and Yang (2007) made a review of the literature related to the SSME stating that there is a lack of research in the service management related to the integration of business and technology, there is no clear framework for SSME, and a few research on service engineering and service innovation. They mention the increasing interest toward understanding service systems for service management and engineering. They studied the services field and defined services systems as networks, composed of people, technologies, and organizations (Maglio, Srinivasan, Kreulen, \& Spohrer, 2006), creating value to the customers. They presented the service systems giving the examples of education, IT service delivery centers and patents. Thus, there are many types of services' firms as the consulting firms providing support for development of other firms - services development, the firms providing information and communication technologies infrastructures-IT-services, the firms providing after-sales services to the products.

The after-sales services are the services provided to the customers of the firms. For instance, in the automotive industry, they consist in providing technical assistance, through repair solutions and spare parts changes (Taifi, 2008) to the automobile customers. Firms in different industries use the after-sales services to achieve customer satisfaction. In the automotive industry, Alexander, Dayal, Dempsey, and Vander Ark (2002) and Wheelwright and Clark (1992) mentioned the importance of the after-sales services integration in the idea generation of the new product development. Saccani, Johansson, and Perona (2007) addressed the different possible configurations-vertical integration, centralization and decoupling of the after-sales services supply chain focusing on the internal processes of the after-sales services-field technical assistance, spare parts distribution, and customer care. Taifi, Corallo, and Passiante (2008) mentioned the importance of structuring the after-sales services firms into networks for managerial purposes or strategic communities of firms to grasp technical knowledge for innovation.

\section{Business Networks and Processes}

Firms develop relationships with partners for collaboration in the markets (Ring \& Van de Ven, 1994) and 
acquire information and knowledge. There are many types of partners as the suppliers, customers, research centers, and services firms and each one of them has a specific role according to its position in the product development process or the value chain; these partners are functional sources of innovation. The different relationships among the partners are structured according to the roles and functions of each of them (Ring \& Van de Ven, 1992) and the network structure is different according to the type of networks. There are knowledge networks (Seufert, von Krogh, \& Bach, 1999) for knowledge sharing among individuals or organizations, and strategic networks (Gulati, 1998) as joint ventures, strategic alliances. There are also business networks (Holm, Eriksson, \& Johanson, 1999) formed for the managerial purposes as for the business relationships for the supply of product components or after-sales services.

The processes and relationships among the actors involved in the business networks of after-sales services create inter-dependences and mutual commitments (Taifi et al., 2008) that lead to value creation. The business processes, among the actors, are developed through the use of IT-based information systems or face-to-face mechanisms (Taifi, 2008). The use of information technology creates value by supporting differentiation strategies (Porter \& Millar, 1985) and these processes shape the structure of communication among the actors in the business networks.

\section{Strategic Management}

The entrance in a new market is a traditional way to firm's growth in industrial sectors, but it is often associated with high corporate risks in terms of specific investments, as well as for organizational challenges. The area of after-sales can represent critical revenue for industrial producers, as we consider the following assumptions (Bendig, Irion, \& Oettgen, 2006):

- Some of the most relevant life cycle costs related to industrial goods and plants come from maintenance, distribution of spare parts, and so on;

- If compared to the production of industrial goods, the financial investments for the supply of after-sales services is clearly lower; instead, its potential return on investment is clearly higher compared to the product and plant sale;

- The profits gained through the after-sales services for industrial products are less cyclical than the products sales, representing a continuous inflow suitable for the corporate financial planning;

- The human resources and the technical know-how able to provide after-sales services, and the reputation required by service providers to succeed are always consolidated when these services are developed by the same producers of the goods to which they are related.

To ensure the growth of a company that faces the position in an unattractive market, due to the existence of high competitive forces (Porter, 1980), two alternative strategic choices can be considered, to be able to ensure the growth of the companies to a cumulative effect of new and product related revenues (Bendig et al., 2006):

- The entrance in a new geographical market with new products or services;

- The widening or the enrichment of the product portfolio within its original competences with the focus on a new service market.

Under a corporate perspective, these alternatives represent the entrance in a new market; in particular for the second choice, after-sales services can be assumed to be a strategic and natural follow-up for an industrial producer (Bendig et al., 2006). 


\section{Research Framework and Questions}

Afuah (2003) insisted on the importance of understanding innovation management and presented the profit chain framework and the different sources of innovation. The profit chain consists in the necessary elements to create value; the assets and the competences needed according to the nature of innovation-incremental or radical, and derived from the internal and external environments (Prahalad \& Hamel, 1990). The functional sources of innovation are the internal value chain $-R \& D$, Manufacturing and Marketing, and its external value chain—suppliers, competitors, customers and others. The after-sales services, as services, are in the marketing or the related industries. Besides, according to Schumpeter (1934), the sources of innovation are the creation of a new business, the launch of a new product or service, or the merger or the acquisition of firms, and the entrance into a new market requires the sources of innovation (Geroski, 1991).

In this research, combining the concepts of Afuah (2003), Schumpeter (1934), and Geroski (1991) about the sources of innovation, the after-sales services can be a functional source of innovation for the development of new products and services, a new business and a mean for the entrance into a new market. The after-sales services are a source of innovation and it also benefits from value creation. Based on the profit chain of Afuah (2003), a value creation chain for the after-sales services in Figure 1 allows the analysis of the internal and external environment, that is a radical innovation, and to derive the assets and competences that lead to value creation for the after-sales services.

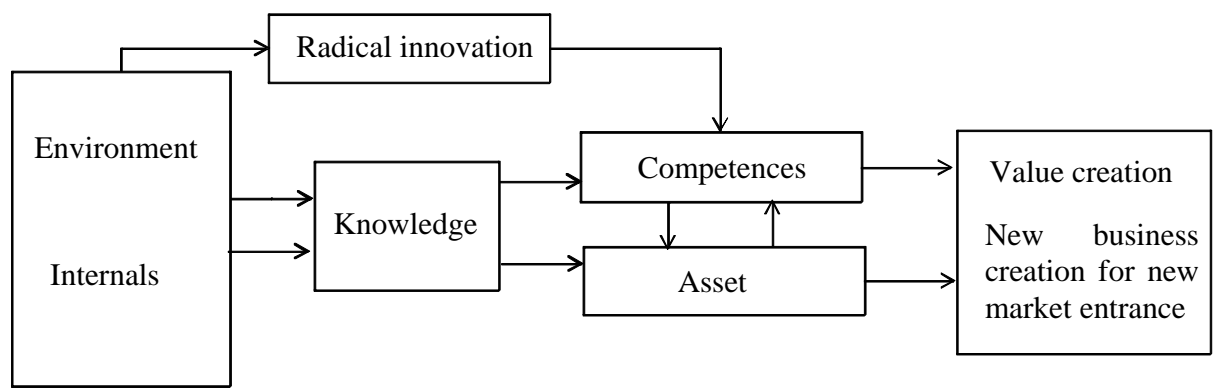

Figure 1. Value creation chain for ASS: New ASS business creation.

The research questions are devised as follows:

Main question:

- What does value creation for the after-sales services (ASS) mean?

Sub-questions:

- What are the value creations for the ASS?

- Which are the elements leading to value creation for ASS?

-What are the types of elements leading to ASS value creation?

\section{Research Method}

Case studies research is used to investigate on real and contemporary contexts and events (Yin, 1994). Since the research objective is to investigate on value creation for the after-sales services, the case study mainly regards the creation of a new business of sales and after-sales services. However, another business responsible of the design, manufacturing and also the sales, is slightly presented since it is the most important partner of the new business of sales and after-sales services. The objective of these businesses is to enter new markets. The sales and after-sales services business has been created through the partnership of 
two firms in the aerospace industry. These founders have acquired many competences in different fields in the aerospace industry. Their expertises are similar since both design, produce, and provide after-sales services, but their partnership is also complementary since one is expert in civil aircrafts and the other in a new regional market.

The context of the study, the aerospace industry, is one of the most dynamic and complex environments. It is characterized by various types of actors, systems of collaboration, structures of networks and information systems. It is an environment in which value creation is continuously sought to acquire and sustain competitive advantage at the products, services, systems, structures, and processes levels. Thus, research in the aerospace industry provides many contributions about the complexity of the dynamic environments and many insights at the organizational and strategic levels.

\section{Data Collection}

The main data collection method used in this study consists in interviews with key informants. These latter are the most important people involved in the case study. The case study is about the creation of a new business of sales and after-sales services, thus the key informants are the founders of the new business-managers of one of the founders responsible of the development of the new business, and the new business it self- the managers involved in the organizational and strategic processes of the new business. The founder's managers are the head of CTO process improvement and know-how development and the head of ICT process, and provided data about the method used to develop the business processes and management of the new business. The internal managers are the head of the customer services, the head of the operations and procurement, the head of the ICT department, and the chief executive officer and provided data about the internal and external processes and management of the new business. The results, derived from the interviews, are divided into three sections; the presentation of the internals and the environment of the new business, the new market entrance benefits and the challenges.

\section{Results and Discussions}

\section{Case Study: The New Business Creation}

According to Sinha and Noble (2005), while entering new markets, small firms are able to adapt and pursue emerging opportunities, however, they must have a more complex and studied strategy in comparison with large firms. Besides, small firms can enter later new markets when they are sure to have a competitive advantage. Thus, new market entrance firms' objective is supported by some specific elements. These latter are the enablers of new market entrance. They are the basis for the achievement of competitive advantage and high economic performance. The enablers are related to the internals of the firm in terms of resources, competences, and governance mechanisms, and to the environment of the firm in terms of business relationships, inter-dependencies, and network configuration with suppliers, customers, and partners. Following the logic of the "Porter's five forces" framework for the industry analysis, here we use the term environment to refer the forces that determine the competitive intensity and therefore attractiveness of a market. They are to be intended as the micro environment, excluding the macro environmental exogenous variables of the Industry. They focus on the market characteristics that affect the corporate ability to serve its customers and make a profit (Porter, 1979).

The internals. Firms A and B, from different countries, in the aerospace industry, decide to collaborate and 
create a new business for the sales and after-sales services activities. In the past, firm A has created the other business of design, manufacturing, and sales. Both firms A and B have acquired through time major competences in these fields from past experiences in the aerospace industry. The purpose of the partnership is to enter new markets-market $\mathrm{C}$ and market $\mathrm{R}$; The $\mathrm{C}$ market refers to the type of product which is the civil market and the $\mathrm{R}$ market refers to the regional markets that are two markets in this case- R1 and R2. In fact, market-orientation builds capability (Hurley \& Hult, 1998) and leads to better business performance (Narver \& Slater, 1990). The partnership, gives birth to the new business-SAS in Table 1 and the other business is DMS. This latter DMS is dedicated to the design, manufacturing of the $\mathrm{C}$ products and to the sales of these in market R1. DMS is also created to separate the firm A's C design and manufacturing activities from the original ones, whereas SAS is dedicated to the selling of the $\mathrm{C}$ products in the $\mathrm{R} 2$ market and to the after-sales services in the entire $\mathrm{R}$ market and it is independent from firms A and B. SAS's corporate identity is in the phase of creation. The mission, objectives, and values are defined by firms A and B in order to enter in a strategic manner the new markets. For instance, one of the strategies of SAS is the green environment, thus, it bases its products on green technologies and the safety of the environment.

Table 1

The Division of Tasks Among DMS and SAS for the C Market Activities

\begin{tabular}{|l|l|}
\hline DMS & SAS \\
\hline Design & Sell in R2 market \\
\hline Production & \\
\hline Sell in R1 market & After-sales services in the R market \\
\hline Distribution of spare parts & \\
\hline
\end{tabular}

Concerning the governance, DMS is majorly owned by firm A and SAS is almost equally owned by firms A and B and this latter has more ownership. Firms A and B have different types of organizational structures, management, measurement systems, and knowledge sharing principles. The cultural differences have an impact on firms (Nonaka \& Takeuchi, 1995). Thus, the business processes among DMS and SAS are in the phase of development to align and standardize the inter-organizational activities. The building of a process-based organization facilitates communication and accelerates data exchange within the firms (Corallo, Margherita, Storelli, \& Scalvenzi, 2009; Corallo, Margherita, Scalvenzi, \& Storelli, 2010). SAS top-management is dynamic, appointed every three years, and is willing to avoid structure rigidity and allow flexibility. SAS lower-levels of management involves ICT, customer services and operations departments. The decision-making mechanisms, at these levels, are decentralized and orchestrated by both firms A and B. The process of decision-making is designed through hierarchical decentralization and influenced by the decision-specific characteristics (Papadakis, Lioukas, \& Chambers, 2009). At each level of management, specific decisions are made, which lead to a strategic decision-making process.

Besides, the on-going operations of SAS are also due to the accumulated experience of both firms A and B in the aerospace sector and in the managerial and professional practices. The team who created SAS is characterized by a high level of diversity: its components belong to 15 different countries, half of them come from realities outside the main companies, thus bring the perspectives and competences of both customers and producers. The technological experience, thus, the level of competences, is primordial in the success of entering new markets (King \& Tucci, 2002; Martin \& Mitchell, 1998) and the management of the competences through 
ICTs accelerates the competences' development (Corallo, Lazoi, Taifi, \& Scalvenzi, 2008; Corallo, Lazoi, Margherita, \& Scalvenzi, 2010). The customer services are the core process of SAS; its competences are derived from the past experiences of the founders. The customer services consist in four main blocks which are the training center, the spare parts section, the information exchange organization, and the suppliers section. There are the most important activities for the functioning of the new business. The suppliers and spare parts section perform sometimes the same tasks since the spare parts come from the suppliers. Thus, there are cross-functional and parallel activities which need to be optimized and focalized in the future. The training center is responsible of providing the necessary trainings to the human resources involved in the operations, the sales and after-sales services activities and this is taken into consideration the cultural differences since the human resources are multi-cultural. The section responsible of the information exchange among SAS and its partners is mainly governed by the top-management for security of intellectual capital.

The environment. The firms, in the new market, are partners, competitors, or co-opetitors and they have experience in the market, thus technical knowledge about the business environment. The new entering firms create partnerships in order to acquire the necessary resources to achieve competitive advantage in the market. Thus, they create strong ties with the suppliers, customers, and other partners for collaboration in Figure 2. In order to create partnerships, SAS makes a benchmark, at the prices levels, of the different services' firms existing on the market in order to select the most strategic ones since the reliability of the services also depends on them. SAS focuses on both the quality and economic aspects.

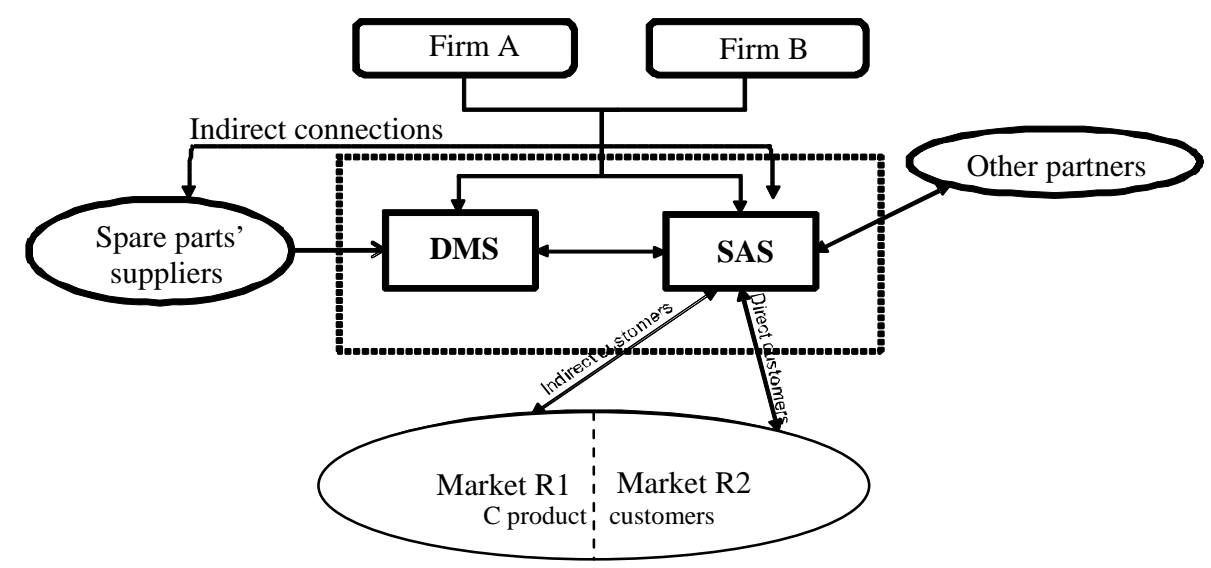

Figure 2. Value creation chain for ASS: New ASS business creation.

For the manufacturing, suppliers are in direct connection with MS and this latter supplies SAS with the necessary spare parts for the after-sales services in Table 2. The spare parts' suppliers are among the most strategic suppliers for the on-going operations of DMS and SAS. SAS can enter in direct connection with the suppliers for information and repair solutions. Thus, with respect to SAS, there are direct and indirect suppliers. The direct suppliers are the ones providing information and repair solutions while the indirect suppliers are to whom DMS plays the intermediary role. The suppliers have a high purchasing power since they are the only ones in direct contact with DMS, thus, they are selected according to their competences in the C market and to the strength of relationship they have with the customers; the direct and indirect connections with the suppliers enhance the innovation performance (Ahuja, 2000). 
Table 2

The Role of the Suppliers of Spare Parts With Respect to SAS

\begin{tabular}{|l|l|}
\hline SAS Suppliers & Activities \\
\hline Direct suppliers & $\begin{array}{l}\text { Repair solutions } \\
\text { Information needs }\end{array}$ \\
\hline Indirect suppliers & Spare parts supply \\
\hline
\end{tabular}

SAS is responsible of the after-sales services in the entire $\mathrm{R}$ market, but the sales are made by DMS and SAS in the R2 and R1 markets, respectively in Figure 3. Thus, SAS customers are divided into two parts in Table 3. The direct customers are in the $\mathrm{R} 2$ region and the indirect ones are in the $\mathrm{R} 1$ region. The direct customers collaborate with SAS for the purchasing and for the after-sales services whereas the indirect customers collaborate with SAS for the after-sales services only. The firms' main goal is to create value to its customers that is higher than the costs of value creation (Porter, 1985) to achieve economic performance and competitive advantage. For that, firms investigate on the customer needs, thus, they are considered as co-value creators (Prahala \& Ramaswamy, 2000) since they have strategic knowledge about the products of DMS and SAS. The customers' feedbacks can be used to develop the products and the after-sales services.
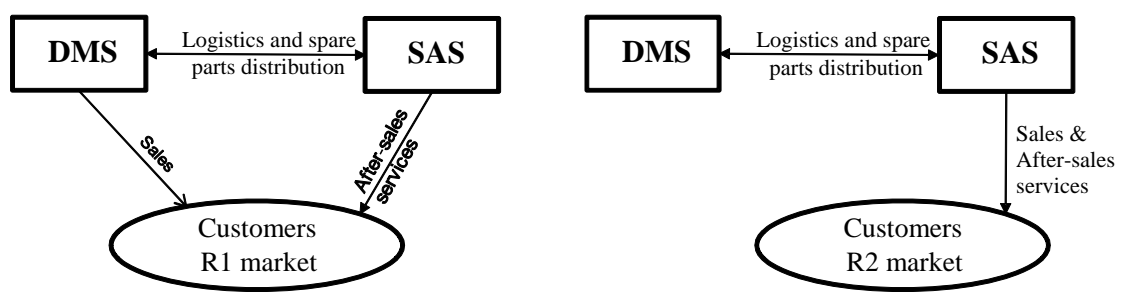

Figure 3. The division of tasks among DMS and SAS according to the types of R market.

For the creation of SAS, other types of partners are involved in the sales and after-sales services for the management of the product life cycle and for the logistics. And initially other partners are involved for the development of SAS internal processes and SAS external processes with DMS and the customers, and a network of specialist warehouses are selected, based on quality criteria and certifications to provide the after-sales services.

Table 3

The Types of Customers With Respect to SAS

\begin{tabular}{|l|l|l|}
\hline SAS customers & Activities & Market \\
\hline Direct customers & $\begin{array}{l}\text { Purchasing } \\
\text { After-sales services }\end{array}$ & R2 \\
\hline Indirect customers & After-sales services & R1 \\
\hline
\end{tabular}

Through the collaboration with the suppliers and other partners, SAS and DMS are outsourcing the logistics related to after-sales services, some of the product life cycle management and of the after-sales services. Outsourcing is a fundamental aspect of market-oriented firms (Singh, 2009). Firms build capacities through outsourcing (Kotabe \& Murray, 2004), however, firms must not use a too complex structure in order not to lose capability and decision-making speed, and adopt the make or buy analysis to share business risks and costs (Williamson, 1975, 1985). The inter-dependencies, as a result of the partnerships in the market, as for the logistics and the product lifecycle management, create an open system environment in which the operations management is based on information and communication technologies. 
Firms A and B, the founders of DMS and SAS, have different networks of partners and are members of other markets. In the new individual market, DMS and SAS are new partners while in other markets their founders are competitors. Firms that have contacts with competitors in other markets can reduce competition in individual markets since this leads the competitors to stop competitive pressure (Barnett, 1993).

\section{New Market Entrance Benefits}

The new businesses have new top-management for the on-going operations of the firms in the new market for the sales and after-sales services. According to Stephan, Murmann, and Boeker (2003), new CEOs are not involved in the firm's formalized external network: the top-management of the new businesses has competitive advantages for market entry independent from how competitors operate in the market. For instance, the partnerships for logistics and product lifecycle management are competitors in the new market. There is the creation of co-opetition.

The new businesses, DMS and SAS, while entering the new market, create a win-win situation by which both generate benefits in Table 4. The new market entrance provides return to investment from new types of products, thus, connections with new customers. This is a part of the diversification strategy of the firms for higher economic performance acquisition (Miller, 2004, 2006). Also, both firms acquire new knowledge about the products and the product lifecycle management, knowledge about design and manufacturing, and sales and after-sales services. As a result, there is the integration between the different steps of the product development process that goes from the design to the after-sales services.

Table 4

The Drivers of the New Market Entrance Benefits

\begin{tabular}{|l|l|}
\hline DMS & SAS \\
\hline Position into civil market & Positions into regional market \\
\hline Design, produce & Sell \\
\hline Logistics and strategic management & Logistics and strategic management \\
\hline Outsourcing of customer support & Outsourcing of customer support \\
\hline Partnerships & Partnerships \\
\hline
\end{tabular}

\section{New Market Entrance Challenges}

The challenges to new market entry are related to the product differentiation, capital investment, transaction costs, and access to distribution channels (Porter, 1979). This relates to competition in the industry structure (Harrigan, 1981). The new businesses have different products, have made major investments for the manufacturing and the after-sales services and do share the risks in their network of partners. According to Sinha and Noble (2005), firms must know when to pass on an emerging market. Thus, a careful analysis of the market is necessary to understand its dynamics as the development's speed of the market, the precise return to investment, and the alignment of the market with the business strategy. For the after-sales services, studying the automotive market provides the significant insights for high economic performance (Huber \& Bauer, 2009).

Besides, Stephan et al. (2003) stated that top-management operations are sensitive, in individual markets, to connections with competitors in other markets. They compare the behavior of longer-tenured CEOs and new CEOs behavior while entering a new market. They found out that longer-tenured CEOs respond to competitive prescriptions implicit in the level of their firm's multi market ties, whereas newer CEOs use their competitors as models for the decision-making processes while entering the new market. This behavior leads to high costs 
for the organization. Thus, the market entrance can have high costs of investments, in the case of decision-making replication, which needs to be overcome through the sharing of costs and risks with the partners.

In dynamic markets, new firms must have dynamic capabilities to overcome competition. Dynamic capabilities are the enablers to fast response to the environment to achieve economic performance (Teece, 2007; Eisenhardt \& Martin, 2000). For instance, organizational capabilities are the results of an organizational-learning process (Schreyogg \& Kliesch-Eherl, 2007) and the results of the response to specific challenges in the market (Winter, 2003). Continuous changes are conducted at all levels of the firm and not only at the managerial level (Leonard-Barton, 1995). Thus, in the long-term, changes in the organizational structure of the firms can occur in order to adapt to the dynamic market. However, the firms in the market must keep the initial business objectives.

\section{Value Creation for After-sales Services: A Typology of Guidelines}

The purpose of this study is to investigate on the after-sales services value creation. We presented the case of the creation of a new business of sales and after-sales services for the purpose of entering a new market. We argue that the after-sales services are not only a source of innovation but that they also benefit from value creation. The new business represents value creation for the after-sales services. At the same time, the entrance into the new market creates value for the after-sales services new business in Figure 4. The creation of a new business and the entrance into a new market requires many organizational and strategic actions for success. Thus, we investigated on the internals and the environment of the new business, and on the assets and competences of this new business. We derive the organizational and strategic elements leading to value creation for the ASS. We provide two types of guidelines for after-sales services value creation related to the organization and strategy; the innovative organizational management and the innovative strategic processes.

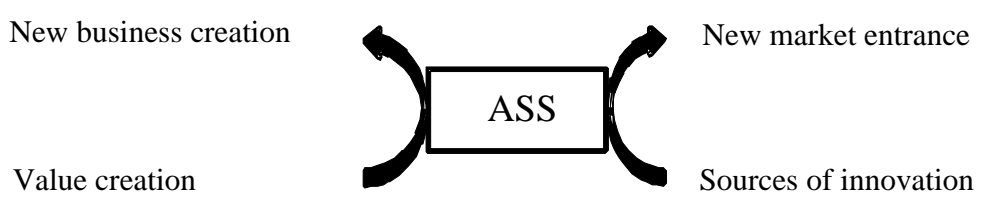

Figure 4. Value creation for ASS and the ASS as a source of innovation.

\section{New Business Creation for ASS}

The organizational management of the new business is related to the governance mechanisms and the network configurations (see Table 5). The governance mechanisms must be adapted to the different cultures of the human resources involved in the new business. These mechanisms, when decentralized, will facilitate decision-making and accelerate the provision of the after-sales services when needed. The network configuration is related to the structure of collaboration among the different partners and the new business. The partners of the new business can belong to different networks, thus there can be a kind of integration of different networks due to the non-exclusive collaboration among all the actors. However, the direct connections with the suppliers of components for the after-sales services are essential for the achievement of fast and efficient operations.

The strategic processes and management of the new business in Table 5 are related to the resources and competences available to the new business and the inter-dependencies and business relationships with the 
partners. The new business of ASS must have the necessary resources for the success of the ASS as the infrastructures, the information technologies, and the material for the ASS, and the competences of the human resources are primordial to the success of the after-sales services. The new business must have the necessary material and the adequate competences to provide efficient after-sales services. For that, the inter-dependencies and the business relationships play a key role for the necessary acquisition of external knowledge or material and outsourcing of some operations for the after-sales services.

Table 5

New Business Creation as a Value Creation for ASS

\begin{tabular}{|l|l|l|}
\hline New business creation & Internal environment & External environment \\
\hline Guidelines typologies/Guidelines for & Governance mechanisms & Network configuration \\
\hline Organizational management & Resources and competences & $\begin{array}{l}\text { Inter-dependencies } \\
\text { Business relationships }\end{array}$ \\
\hline Strategic processes &
\end{tabular}

\section{ASS and the New Market Entrance}

The new business of after-sales services entering the new market can generate various types of values. These latter are either organizational or strategic but also either positive or negative in Table 6. The organizational management values are related to the differentiated management and co-opetition with the competitors. In order to achieve competitive advantage, the new business management must be differentiated from the competitors. For instance, the new business entering the new market can create partnerships with the competitors-co-opetition, for the acquisition of new resources and competences for the development of the new business, however, the new business must not replicate the management styles of the competitors in order not to become a clone of the competitors and to risk to lose the competitive advantage of the new market entrance.

Table 6

Value Creation and New Market Entrance

New market entrance

\begin{tabular}{|l|l|l|}
\hline Value creation & Benefits & Challenges \\
\hline Organizational management & $\begin{array}{l}\text { Differentiated management and co-opetition } \\
\text { with competitors }\end{array}$ & Replication of competitors decision making \\
\hline Strategic processes & $\begin{array}{l}\text { Return to investment } \\
\text { New knowledge acquisition } \\
\text { NPD integration }\end{array}$ & $\begin{array}{l}\text { Risks and costs sharing } \\
\text { Dynamic capabilities }\end{array}$ \\
\hline
\end{tabular}

The new business entering the new market can also generate strategic values as the different returns to investment. The return can be financial, thus it profits from the operations of the after-sales services, however, the new business must keep, even in cases of high profits, sharing risks and costs with the partners. The return can also be related to the new knowledge acquisition in the new market that can be useful for the development of the operational activities of the after-sales services, however, the new knowledge acquisition must also be focused on building new capacities to sustain competitive advantage in the market. Besides, as another strategic value, the networking with the partners, involved in the value chain of the new business, can create a value network that lead to the integration of the different steps of the product development process that goes from the design to the after-sales services of the products. 


\section{Limitations and Future Research}

The objective of the study was to further the understanding of value creation for the after-sales services. We focused on the elements leading to the value creation and provided a typology of guidelines and guidelines for the after-sales services value creation. These were derived from a case study in the aerospace industry. The guidelines and their typologies have important implications for the organizational and strategic management fields. Value creation for the after-sales services, from an organizational and strategic perspective, can also regard the inter-organizational information systems and technologies and the creation of new after-sales services, and even another typology of guidelines. In fact, a network perspective for value creation for the after-sales services can be analyzed. Further research must be done to develop these perspectives on the after-sales services value creation through the same case study in the aerospace industry or through other case studies in complex industries-automotive or software industries. Also, further research can be done on the impact of the integration of various actors in the value chain of the after-sales services on value creation for the after-sales services and the factors in the environment urging firms to integrate vertically.

\section{References}

Afuah, A. (2003). Innovation management: Strategies, implementation and profits. New York, N.Y.: Oxford university press.

Ahuja, G. (2000). Collaboration networks, structural holes, and innovation: A longitudinal study. Administrative Science Quarterly, 45(3), 425-455.

Alexander, W. L., Dayal, S., Dempsey, J. J., \& Vander Ark, J. D. (2002). The secret life of factory service centers. The McKinsey Quarterly, 3, 106-115.

Barnett, W. P. (1993). Strategic deterrence among multipoint competition. Industrial and Corporate Change, 2, 249-278.

Barnett, W. P., Greve, H. R., \& Park, D. Y. (1994). An evolutionary model of organizational performance. Strategic Management Journal, 15, 11-28.

Baumeister, R. F. (1993). Exposing the self-knowledge myth. Contemporary Psychology, 38, 466-467.

Bendig, T., Irion, T., \& Oettgen, N. (2006). The strategic importance of after-sales services for the insurance of growth in customer-value-oriented management: An observation of small and medium-sized industrial goods manufacturers. Retrieved from http://www.amfiteatrueconomic.ase.ro/arhiva/pdf/no20/revista_fulltext.pdf

Corallo, A., Lazoi, A., Taifi, N., \& Scalvenzi, M. (2008). Efficient IT-based competence management: An aerospace company case study. Proceedings of AISS 2008: Managing Uncertainty and Competition Through Dynamic Learning Networks.

Corallo, A., Lazoi, M., Margherita, A., \& Scalvenzi, M. (2010). Optimizing competence management processes: A case in the aerospace. Business Process Management Journal, 16(2), 297-314.

Corallo, A., Margherita, A., Scalvenzi, M., \& Storelli, D. (2010). Building a process-based organization: The design roadmap at superjet international. Knowledge and Process Management, 17(2), 49-61.

Corallo, A., Margherita, A., Storelli, D., \& Scalvenzi, M. (2009). Building a process-based organization and network. Proceedings of AISS 2009: Value Creation Networks: New Management Practices, Ostuni, Italy.

Duncan, G. J., \& Brooks-Gunn, J. (1997). Consequences of growing up poor. New York, N.Y.: Russell Sage Foundation.

Eisenhardt, K. M., \& Martin, J. A. (2000). Dynamic capabilities: What are they?. Strategic Management Journal, 21, $1105-1121$.

Geroski, P. (1991). Market dynamics and entry. Oxford, U.K.: Blackwell.

Gulati, R. (1998). Alliances and networks. Strategic Management Journal, 19, 293-317.

Harrigan, K. R. (1981). Barriers to entry and competitive strategies. Strategic Management Journal, 2(4), 395-412.

Helfer, M. E., Keme, R. S., \& Drugman, R. D. (1997). The battered child (5th ed.). Chicago, I.L.: University of Chicago Press.

Henry, W. A. (1990). Making the grade in today's schools. Time, 135, 28-31.

Holm, D. B., Eriksson, K., \& Johanson, J. (1999). Creating value through mutual commitment to business network relationships. Strategic Management Journal, 20(5), 467-486.

Huber, F., \& Bauer, S. K. (2009). High performance in after-sales support services in the automotive industry. International Journal of Automotive Technology and Management, 9(3), 334-347.

Hurley, R. G., \& Hult, T. G. (1998). Innovation, market orientation and organizational learning: An integration and empirical 
examination. Journal of Marketing, 3(62), 42-54.

King, A. A., \& Tucci, C. L. (2002). Incumbent entry into new market niches: The role of experience and managerial choice in the creation of dynamic capabilities. Management Science, 48, 171-186.

Kotabe, M., \& Murray, J. (2004). Global sourcing strategy and sustainable competitive advantage. Industrial Marketing Management, 33(1), 7-14.

Laplace, P. S. (1951). A philosophical essay on probabilities. New York, N.Y.: Dover.

Leonard-Barton, D. (1995). Wellsprings of knowledge: Building and sustaining the sources of innovation. Boston, M.A.: Harvard Business School Press.

Li, H. F., Wang, J. J., Yu, H. L., \& Yang, D. L. (2007). Services sciences, management and engineering: A literature review in the perspective of management science (pp. 1438-1441). Proceedings of IEEE-IEEM.

Maglio, P. P., Srinivasan, S., Kreulen, J. T., \& Spohrer, J. (2006). Service systems, service scientists, SSME and innovation. Communications of the ACM, 49(7), 81-85.

Martin, X., \& Mitchell, W. (1998). The influence of local search and performance heuristics on new design introduction in a new product market. Research Policy, 26, 753-771.

Mattmüller, R., \& Irion, T. (2004). Der konzeptionelle Status quo von After-Sales-Services im Industriegüterbereich. In H. Kaerner, M. Kasper, \& R. Mattmüller (Eds.), After-sales: Der Service macht den Gewinn (pp. 21-34). Frankfurt.

Miller, D. J. (2004). Firms' technological resources and the performance effects of diversification: A longitudinal study. Strategic Management Journal, 25(11), 1097-1119.

Miller, D. J. (2006). Technological diversity, related diversification and firm performance. Strategic Management Journal, 27(7), 601-619.

Moller, G. (2002). Ripples versus rumbles. Scientific American, 287(2), 12.

Narver, J. C., \& Slater, S. F. (1990). The effects of a market orientation on business profitability. Journal of Marketing, 54(4), 20-35.

Nonaka, I., \& Takeuchi, H. (1995). The knowledge-creating company: How Japanese companies create the dynamics of innovation. New York: Oxford University press.

O’Neil, J. M., \& Egan, J. (1992). Men's and women's gender role journeys: Metaphor for healing, transition, and transformation. In B. R. Wainrib (Ed.), Gender issues across the life cycle (pp. 107-123). New York, N.Y.: Springer.

Papadakis, V. M., Lioukas, S., \& Chambers, D. (1998). Strategic decision-making processes: The role of management and context. Strategic Management Journal, 19, 115-147.

Plath, S. (2000). The unabridged journals. In K. V. Kukil (Ed.). New York, N.Y.: Anchor.

Porter, M. (1985). Competitive advantage. New York: Free press.

Porter, M. E. (1979). How competitive forces shape strategy. Harvard business Review, 57(2), 137-145.

Porter, M. E. (1980). Competitive strategy: Techniques for analyzing industries and competitors. New York: Free Press.

Porter, M. E., \& Millar, V. E. (1985). How information gives you competitive advantage. Harvard Business Review, 63(4), 149-160.

Prahalad, C. K., \& Hamel, G. (1990). The core competence of the corporation. Harvard Business Review, 68(3), 79-91.

Prahalad, C. K., \& Ramaswamy, V. (2000). Co-opting customer competence. Harvard Business Review, 1(78), 79-87.

Ring, P. S., \& Van de Ven, A. H. (1992). Structuring cooperative relationships between organizations. Strategic Management Journal, 13(7), 483-498.

Ring, P. S., \& Van de Ven, A. H. (1994). Developmental processes of cooperative inter-organizational relationships. Academy of Management Review, 19, 90-118.

Saccani, N., Johansson, P., \& Perona, M. (2007). Configuring the after-sales services supply chain: A multiple case study. International Journal of Production Economics, 110, 52-69.

Schreyogg, G., \& Kliesch-Eberl, M. (2007). How dynamic can organizational capabilities be? Towards a dual-process model of capability dynamization. Strategic Management Journal, 28, 913-933.

Schumpeter, J. A. (1934). The theory of economic development: An inquiry into profits, capital, credit, interest, and the business cycle. Cambridge, M.A.: Harvard University Press.

Seufert, A., von Krogh, G., \& Bach, A. (1999). Toward knowledge networking. Journal of Knowledge Management, 2(3), 180-190.

Singh, S. (2009). How market orientation and outsourcing create capability and impact business performance. Thunderbid International Business Review, 51(5), 457-471. 
Sinha, R. K., \& Noble, C. H. (2005). A model of market entry in an emerging technology market. IEEE Transactions on Engineering Management, 52(2), 186-198.

Stephan, J., Murmann, J. P., \& Boeker, W. (2003). Bringing managers into theories of multimarket competition: CEOs and the determinants of market entry. Organization Science, 14(4), 403-421.

Taifi, N. (2008). Collaborative knowledge networks: Lessons to learn from a large automotive company (pp. 423-429). Proceedings of the 3rd IFIP Summer School.

Taifi, N., Corallo, A., \& Passiante, G. (2008). The strategic orientation of the managerial ties. International Journal of Knowledge and Learning, 4(6), 613-624.

Teece, D. J. (2007). Explicating dynamic capabilities: The nature and micro-foundation of sustainable enterprise performance. Strategic Management Journal, 28, 1319-1350.

Wheelwright, S. C., \& Clark, K. B. (1992). Revolutionizing product development. New York: Free Press.

Wiener, P. (1973). Dictionary of the history of ideas. New York, N.Y.: Scribner's.

Williamson, O. E. (1975). Markets and hierarchies. New York: Free Press.

Williamson, O. E. (1985). The economic institutions of capitalism. New York: Free Press.

Winter, S. G. (2003). Understanding dynamic capabilities. Strategic Management Journal, 24(10), 991-995.

Yin, R. (1994). Case study research: Design and methods. Thousand Oaks, C.A.: Sage publications. 